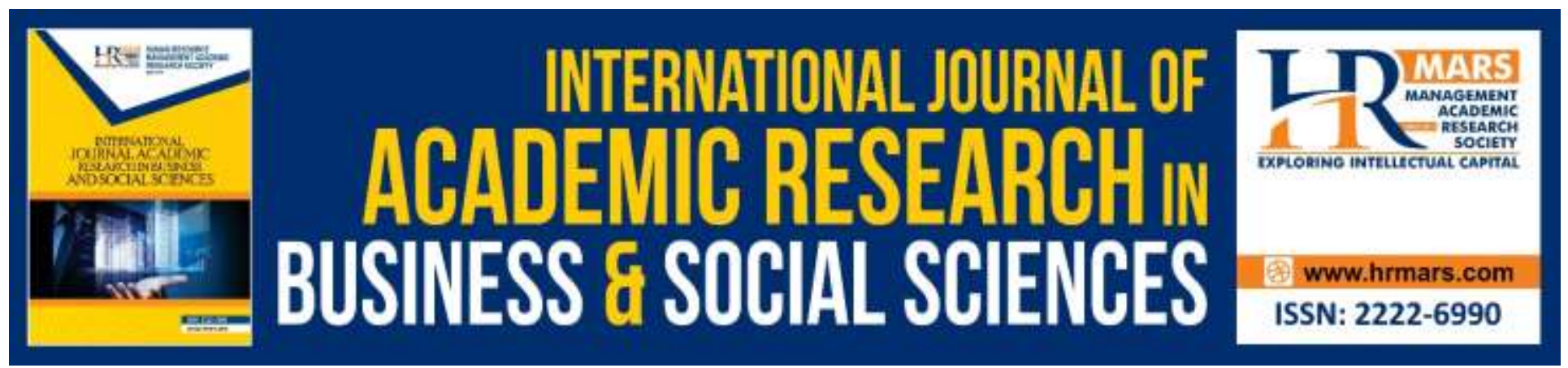

\title{
The Influence Between Metacognition Practice, Students' Learning Commitment and Academic Achievement of Matriculation Students in Physics
}

\section{Norhawani Saaidin}

To Link this Article: http://dx.doi.org/10.6007/IJARBSS/v10-i3/7351

DOI:10.6007/IJARBSS/v10-i3/7351

Received: 21 January 2020, Revised: 26 February 2020, Accepted: 19 March 2020

Published Online: 30 March 2020

In-Text Citation: (Saaidin, 2020)

To Cite this Article: Saaidin, N. (2020). The Influence Between Metacognition Practice, Students' Learning Commitment and Academic Achievement of Matriculation Students in Physics. International Journal of Academic Research in Business and Social Sciences, 10(3), 910-930.

Copyright: (C) 2020 The Author(s)

Published by Human Resource Management Academic Research Society (www.hrmars.com)

This article is published under the Creative Commons Attribution (CC BY 4.0) license. Anyone may reproduce, distribute, translate and create derivative works of this article (for both commercial and non-commercial purposes), subject to full attribution to the original publication and authors. The full terms of this license may be seen

at: http://creativecommons.org/licences/by/4.0/legalcode

Vol. 10, No. 3, 2020, Pg. 910 - 930

http://hrmars.com/index.php/pages/detail/IJARBSS

JOURNAL HOMEPAGE

Full Terms \& Conditions of access and use can be found at http://hrmars.com/index.php/pages/detail/publication-ethics 


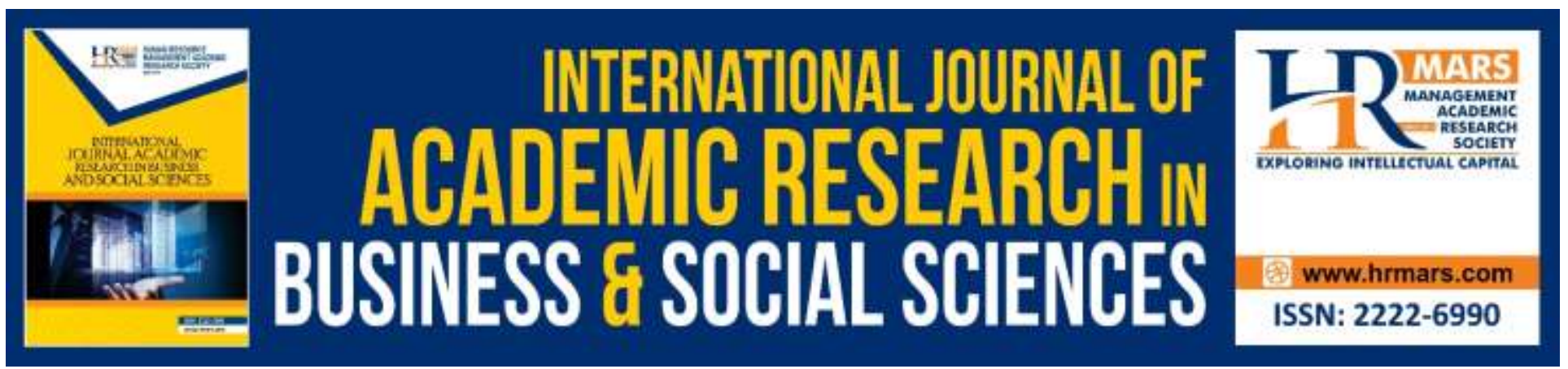

\title{
The Influence Between Metacognition Practice, Students' Learning Commitment and Academic Achievement of Matriculation Students in Physics
}

\author{
Norhawani Saaidin \\ Penang Matriculation College, Penang, Malaysia
}

\begin{abstract}
The study is aimed to explore the influence between the metacognition practice, students' learning motivation, students' learning commitment and academic achievement among matriculation students. The sample consisted of 454 Module 1 and Module 2 matriculation students from Penang Matriculation Students. Data was collected using a questionnaire measuring metacognition, students' learning motivation factors and students' learning commitment factors and diagnostic physics test question to measure the score of academic achievement. For the quantitative method, statistical analysis used is independent t-test sampling. This research used the quantitative method and statistical descriptive independent $t$ - test sampling. The results of the analysis showed that there were no significant differences in all dimension of metacognition, students' learning motivation and students' learning commitment and achievement among Module 1 and Module 2 students. Structural Equation Modeling (SEM) technique analysis showed that the practice of metacognition influenced students' learning motivation and students' learning commitment except extrinsic motivation had a direct, negative relationship with academic achievement. The practice of metacognition showed indirect relationship with academic achievement via intrinsic and extrinsic motivation and affective commitment. In summary, the results of this study provide evidence in support of the influence of metacognition to academic motivation of matriculation students, but via students' learning motivation (intrinsic motivation and extrinsic motivation) and students' learning commitment (affective) as mediator. Therefore, students' learning motivation dimension and students' learning commitment dimension are important in improving physics achievement among matriculation students.
\end{abstract}

Keywords: Influence, Metacognition Practice, Students; Learning Motivation, Student Learning Commitment, Academic Achievement.

\section{Introduction}

For a country that is an emerging economy, education is a very important requirement in the production of human capital quality who will in turn become pillars for the development of the 
INTERNATIONAL JOURNAL OF ACADEMIC RESEARCH IN BUSINESS AND SOCIAL SCIENCES Vol. 10, No. 3, March, 2020, E-ISSN: 2222-6990 @ 2020 HRMARS

country. This is because the standard of education has close associations with the standard of occupation, social status, income and better standard of living. Thus, it is no wonder that academic achievement is the main goal of exceptional students, parents, educators and people from all walks of life (Eccles \& Wigfield, 1989; Sulaiman, 1995).

Therefore, most of the education system in most countries put student achievement as an indicator as to the success of future student ( Yahaya, Boon, Hashim \& Hamid, 2002; Lay, 2007; Zakaria, 2007). Even academic achievements are also made as benchmarks for the efficacy of an educational system ( Ahmad, 2005). For example, studies conducted in Western countries such as the United States emphasise academic excellence as indicators to assess the effectiveness of a school, as well as other aspects. (Gauthier, 1982; Gray, 2004; Sergiovanni, 2001; Shoemaker, 1982; Rowan, 1983; Villanova, 1984). The same situation occurs in Malaysia. Its education system is based on an examination-oriented measure of excellence of a school through public examination results as UPSR, PMR, SPM and STPM (Lay, 2007).

In line with the focus on student achievement, Matriculation colleges and the Matriculation Division of the Ministry of Education in particular, has the vision and mission to produce students who excel academically, have a healthy lifestyle, have outstanding personality and possess soft skills to enter universities (IPT) and this clearly indicates that academic achievement is the main agenda. Matriculation program is one of the Foundation programs for students to qualify themselves to pursue first degree courses at University and this programme commenced in the middle of 1999. This Matriculation program also aims to produce high quality students to enter public institutions of higher learning to pursue science, technology and professional courses as preparation to become viable human capital of the future. (Bahagian Matrikulasi Kementerian Pelajaran Malaysia, 2008).

\section{Problem Statement}

Physics is one core subject taken by Module 1 and Module 2 students as a compulsory subject since semester 1 of the 2011/2012 academic session. Students' grade in Physics is taken into account in determining the students' CGPA together with other subjects under the One Year Programme. Students have to study many topics in Physics. Besides that, they also have to take compulsory subjects such as English, Islamic education/Moral, Dynamic Skills and Co-curricular studies. Given that, science students have to learn many subjects in each semester and this situation causes them to deal with various challenges and pressure to excel in Physics.

According to Halim et.al. (2002), Physics is the most elusive subject as compared to other subjects. The results show that many students consider Physics as a subject that is difficult (Angell et.al. 2004; Seth, Fatin \& Marlina, 2007; Redish, 1994; Zaidi, 2009) since most of the concepts of Physics and science combine abstract concepts and mere academic nature (Samsudin, 2003; Ornek, Robinson \& Haugan, 2008). In addition, Physics is also said to be a subject that involves many formulas, concepts and theories. Thus, according to Aizasharizam (2010), in studying Physics, students need to understand what they learn because when the students remember through understanding they can be successful. Rahman \& Zakaria (1994) explained that when students are not able to understand abstract ideas beyond the limited student experience, it leads to learning through memorization and the ability to only repeat without understanding whatever they have learnt and then express everything that has been memorised when questioned. This passive learning attitude describes why 
INTERNATIONAL JOURNAL OF ACADEMIC RESEARCH IN BUSINESS AND SOCIAL SCIENCES Vol. 10, No. 3, March, 2020, E-ISSN: 2222-6990 @ 2020 HRMARS

most of the students now face problems with Physics especially in solving Physics issues that involve the description of concepts (Seth, Fatin \& Marlina, 2007). Table 1.2 shows that the Physics Mid Semester 1 Test and Mid-semester 2 test results are declining and this is worrying the management of the Matriculation College.

According to Rohana (2007) an effective method for increasing understanding of Physics is that students studying this subject should be active participants in the process of learning Physics and students need to have the ability to think and have knowledge and control of the process of concentration to understand the concepts. The ability of a person learning Physics involves learning how a process happens, what has not been known and is comprised of three levels which are charting the future of what should be learnt, how and when learning and monitoring of process learnt, as well as evaluating what is learnt, done and the result of the process. This process refers to a way to increase awareness of the process of thinking and learning going on. When consciousness exists, one can control his mind with a plan, monitor and evaluate what he has learnt. Hence, the practice is a high-level thinking practice called metacognition. Metacognition is the ability to realize and know the process of the content that occurs in oneself in the capacity of thought and learning (Livingston, 1997; Matlin, 1998).

Metacognition is an important aspect in determining the success or failure of students in learning Physics and it involves problem solving. However, there are many studies indicating that students are still less exposed and weak in Metacognitive skills this (Zan, 2000; Desoete et al., 2001) thus affecting the achievement of solving problems regarding the subject even though the students have the ability and potential in these areas. Thus, the question of the students ' abilities and assumptions, especially those of the matriculation students are bilaterally under investigation because Metacognition is believed to be affecting the achievement of students.

However, according to Subhan (1995), some students are having trouble in their learning due to lack of motivation and psychological problems. This explains the possibility of the existence of the relationship between motivation and Metacognition in affecting the achievement of students (Saemah \& Phillips, 2006). Motivation is the center for the process of integration in which elements of existing internal knowledge is integrated with existing student knowledge. Paulsen \& Gentry (1995) explains that motivation or desire and learning skills is an important part of the learning process. Based on the last study of the learning motivation and learning strategy is a predictor of significant student academic performance. High self-motivation is needed to achieve the highest level of achievement. (Fazilah, 2000). According to Mohamed (2001) and Razik (2002), an emphasis on internal aspects in terms of goal, emotion, self-confidence, as well as image, and self-determination are said to be a measure of high academic achievement. Many studies that were conducted in foreign contexts showed a direct relationship between motivation and achievement (Schraw, Horn, , Thorndike-Christ \& Bruning, 1995, Lee, 2008) as well as indirect relationship between motivation and achievement (VanZile-Tamsen 1998, Convington, 2000). In addition, a number of motivation as well as the teaching goals are also said to contribute to the relationship between metacognition and academic achievement (Pintrich \& DeGroot, 1990). The relationship between these variables especially in the context of matriculation students who need to organize their own learning is very 
INTERNATIONAL JOURNAL OF ACADEMIC RESEARCH IN BUSINESS AND SOCIAL SCIENCES Vol. 10, No. 3, March, 2020, E-ISSN: 2222-6990 @ 2020 HRMARS

much needed and still lacking among them. (Faridah, 2010; Effendi \& Razak, 2006; Saemah \& Phillips, 2006).

Many studies have been conducted to look at the factors that influence the learning and achievement of students in school ( Hataway et.al, 2003; Mastor, Hamzah, Mustapha, Yacob \& Jaafar, 2006). Among the factors that are detected, and need to be heard are closely linked to the commitment of student learning. Commitment plays an important role in order to achieve success in a given subject or effort. Students who fail are said to be not committed to learning. At school, the teachers often stated that the failure of students is due to their negative attitude such as laziness, disinterest and less committed to class.

This attitude is designed from experience and perceptions of a person against a thing or phenomenon (Robbins, 1986). Students ' perception of a subject will form their commitment towards the subject. Due to this, commitment linked to the achievement of students in Physics the then decline usually associated with commitment and sets out the difficult Physics and feel scared to learn Physics and commitment visible factors effective in helping students achieve the result desired learning.

However, students in the matriculation colleges are SPM leavers who have attained excellent results and chose to pursue the matriculation programme without any compulsion from anyone. However, the Matriculation learning environment which is quite different from school requires students to adapt to the learning environment quickly within a short period of time and learn Physics in a very compact syllabus. Thus, the commitment to learn and motivation to learn can influence their achievement, especially in Physics which are often regarded as a difficult subject. Most of the studies just connect with Metacognition (Saemah \& Phillips, 2006), motivational learning with achievement (Brown, 2009; Broussard, 2002; Adnan \& Yusoff , 2010; Schunk, 1991; Pelletier, Vallerand, Briere, Blais, Senecal \& Vallieres, 1992) and study commitment with achievement (Mastor, Hamzah, Mustapha, Yacob \& Jaafar (2006); Ogunleye \& Babajide, 2010; Tahir \& Boon, 2011; Atan, 2007).

Based on a review of available studies, it is clear that all the variables such as Metacognition, motivation to learn and commitment of students and its relationship with students' academic achievements have not been explored simultaneously, especially in the context of the matriculation colleges in the country. Therefore, this study is expected to meet this shortage.

\section{Research Objective}

This study is aimed to examine the relationship between variables of Metacognition, dimensions of learning motivation (intrinsic, extrinsic value assignments, learning control efficacies of belief, self and concern over the test) and the dimensions of learning (commitment affective, cognitive and behavioral) of matriculation students with their achievement, especially in Physics at Penang Matriculation College. In particular, the objectives of this study are to:

1. Identify the relationship between the practice of Metacognition, learning motivation (intrinsic, extrinsic, value of assignments, learning control efficacies of belief, self and concern over the test) and learning commitment (affective, cognitive and behavioral) with the achievements of students learning Physics in the Matriculation Program. 
INTERNATIONAL JOURNAL OF ACADEMIC RESEARCH IN BUSINESS AND SOCIAL SCIENCES Vol. 10, No. 3, March, 2020, E-ISSN: 2222-6990 C 2020 HRMARS

\section{Research Question}

Referring to the objective of the study above, this is the research question for this study:

1. Is there a relationship between Metacognition, motivation to learn and study with commitment and achievements in Physics among the matriculation students?

\section{Literature Review}

There is a study to review the relationship between variables of commitment learn, Metacognition and motivation to learn with students/ academic achievement in Physics. Table 1 shows a summary of the studies carried out.

Table 1: A summary of related studies of the relationship between the dimension of Metacognition, motivation to learn and dimension of commitment to learning

\begin{tabular}{llll}
\hline $\begin{array}{l}\text { Researchers } \\
\text { \& Years }\end{array}$ & Variables Studied & Analysis & Finding \\
\hline Fusco (1995) & $\begin{array}{l}\text { Commitment } \\
\text { Metacognition } \\
\text { Achievement }\end{array}$ & $\begin{array}{l}\text { video } \\
\text { recorder } \\
\text { analysis, } \\
\text { student } \\
\text { protocol }\end{array}$ & $\begin{array}{l}\text { The relationship between commitment } \\
\text { and metacognition with students ' } \\
\text { academic achievement. }\end{array}$ \\
& & $\begin{array}{l}\text { analysis } \\
\text { correlation }\end{array}$ & $\begin{array}{l}\text { Motivation and attitude do not have } \\
\text { significant relationship with } \\
\text { achievements }\end{array}$ \\
\hline
\end{tabular}

From the findings in Table 1, there is research that shows the relationship between commitment and Metacognition (Fusco, 1995) and there is no relationship between commitment attitude with motivation. However, the findings of the study have not been conclusive. This shows that further research needs to be carried out in order to gain a broad and comprehensive result on the role of Metacognition, motivation to learn and studies on student achievement and commitment.

\section{The correlation between students' achievement and commitment}

Past research has shown the relationship between commitment to learn and academic achievement of students. Table 2 shows a summary of the relationship studies which were conducted. 
INTERNATIONAL JOURNAL OF ACADEMIC RESEARCH IN BUSINESS AND SOCIAL SCIENCES Vol. 10, No. 3, March, 2020, E-ISSN: 2222-6990 @ 2020 HRMARS

Table 2: A summary of Studies relating to commitment learn by academic achievement

\begin{tabular}{|c|c|c|c|}
\hline $\begin{array}{l}\text { Researchers } \\
\text { \& Years }\end{array}$ & Variables Studied & Analysis & Finding \\
\hline $\begin{array}{l}\text { Fredricks et al. } \\
(2004)\end{array}$ & $\begin{array}{l}\text { Academic Achievement } \\
\text { Commitment }\end{array}$ & $\begin{array}{l}\text { Correlation } \\
\text { Test }\end{array}$ & $\begin{array}{l}\text { There is a positive relationship } \\
\text { between learning commitment } \\
\text { with academic achievement }\end{array}$ \\
\hline $\begin{array}{l}\text { Saifuddin } \\
\text { (1990) }\end{array}$ & $\begin{array}{l}\text { Commitment to studies } \\
\text { academic achievement }\end{array}$ & $\begin{array}{l}\text { Correlation } \\
\text { Test }\end{array}$ & $\begin{array}{l}\text { The commitment to studies on } \\
\text { schools as a whole showed } \\
\text { significant relationships with } \\
\text { academic achievement }\end{array}$ \\
\hline Kamis (1986) & $\begin{array}{l}\text { Students ' attitude } \\
\text { towards academic } \\
\text { achievement in subjects }\end{array}$ & $\begin{array}{l}\text { Correlation } \\
\text { Test }\end{array}$ & $\begin{array}{l}\text { Students ' attitude to subjects has } \\
\text { significant relationship with } \\
\text { academic achievement }\end{array}$ \\
\hline Bloom (1982) & $\begin{array}{l}\text { Cognitive and affective } \\
\text { factors on academic } \\
\text { achievement }\end{array}$ & $\begin{array}{l}\text { Regression } \\
\text { Test }\end{array}$ & $\begin{array}{l}\text { The cognitive and affective factors } \\
\text { have strong relationships on } \\
\text { academic achievement. }\end{array}$ \\
\hline $\begin{array}{l}\text { Leong et al. } \\
(1990)\end{array}$ & $\begin{array}{l}\text { Cognitive academic } \\
\text { achievement }\end{array}$ & Co Test & $\begin{array}{l}\text { Cognitive dimension or attitudes to } \\
\text { school subjects can affect students' } \\
\text { level of achievement. }\end{array}$ \\
\hline $\begin{array}{l}\text { Nihra } \\
\text { Haruzuan \& } \\
\text { Chandrathevy } \\
\text { (2010) }\end{array}$ & $\begin{array}{l}\text { Achievement and } \\
\text { commitment }\end{array}$ & $\begin{array}{l}\text { Correlation } \\
\text { Test }\end{array}$ & $\begin{array}{l}\text { The attitude of commitment has a } \\
\text { significant relationship with } \\
\text { academic achievements. }\end{array}$ \\
\hline
\end{tabular}

Table 2: A summary of Studies relating to commitment learn with academic achievement (cont'd)

\begin{tabular}{llll}
\hline $\begin{array}{l}\text { Researcher \& } \\
\text { Year }\end{array}$ & Variables Researched & Analysis & Findings \\
\hline Paimin(2009) & $\begin{array}{l}\text { Commitment } \\
\text { Emotion } \\
\text { Academic achievement }\end{array}$ & $\begin{array}{l}\text { Correlation } \\
\text { Test }\end{array}$ & $\begin{array}{l}\text { A significant relationship between } \\
\text { commitment and emotion with } \\
\text { academic achievement. }\end{array}$ \\
\hline $\begin{array}{l}\text { Nur Asyiqin } \\
\text { (2006) }\end{array}$ & $\begin{array}{l}\text { Attitude } \\
\text { Achievement }\end{array}$ & $\begin{array}{l}\text { Correlation } \\
\text { Test }\end{array}$ & $\begin{array}{l}\text { The more positive the students ' } \\
\text { attitude towards teaching and } \\
\text { learning, the higher the } \\
\text { achievement }\end{array}$ \\
\hline $\begin{array}{l}\text { Ogunleye \& } \\
\text { Babajide, }\end{array}$ & Attitude & Achievement & Correlation \\
2002 & Test & $\begin{array}{l}\text { A significant relationship between } \\
\text { commitment to their academic } \\
\text { achievement }\end{array}$ \\
\hline
\end{tabular}

The findings in table 2 shows there is a direct relationship between commitment to learn and the academic achievement (Fredrick et al., 2004; Said \& Chandrathevy 2010; Paimin, 2009; Ogunleye \& 
INTERNATIONAL JOURNAL OF ACADEMIC RESEARCH IN BUSINESS AND SOCIAL SCIENCES Vol. 10, No. 3, March, 2020, E-ISSN: 2222-6990 C 2020 HRMARS

Babajide, 2002. Leong (1990) explain the relationship between the dimensions of commitment, namely direct affective and cognitive commitment with academic achievement. However, studies by Shaifuddin (1997) shows that there is a direct link between commitment and achievement.

\section{Conceptual Framework}

Figure 1: shows the relationship between the main variables of the study.

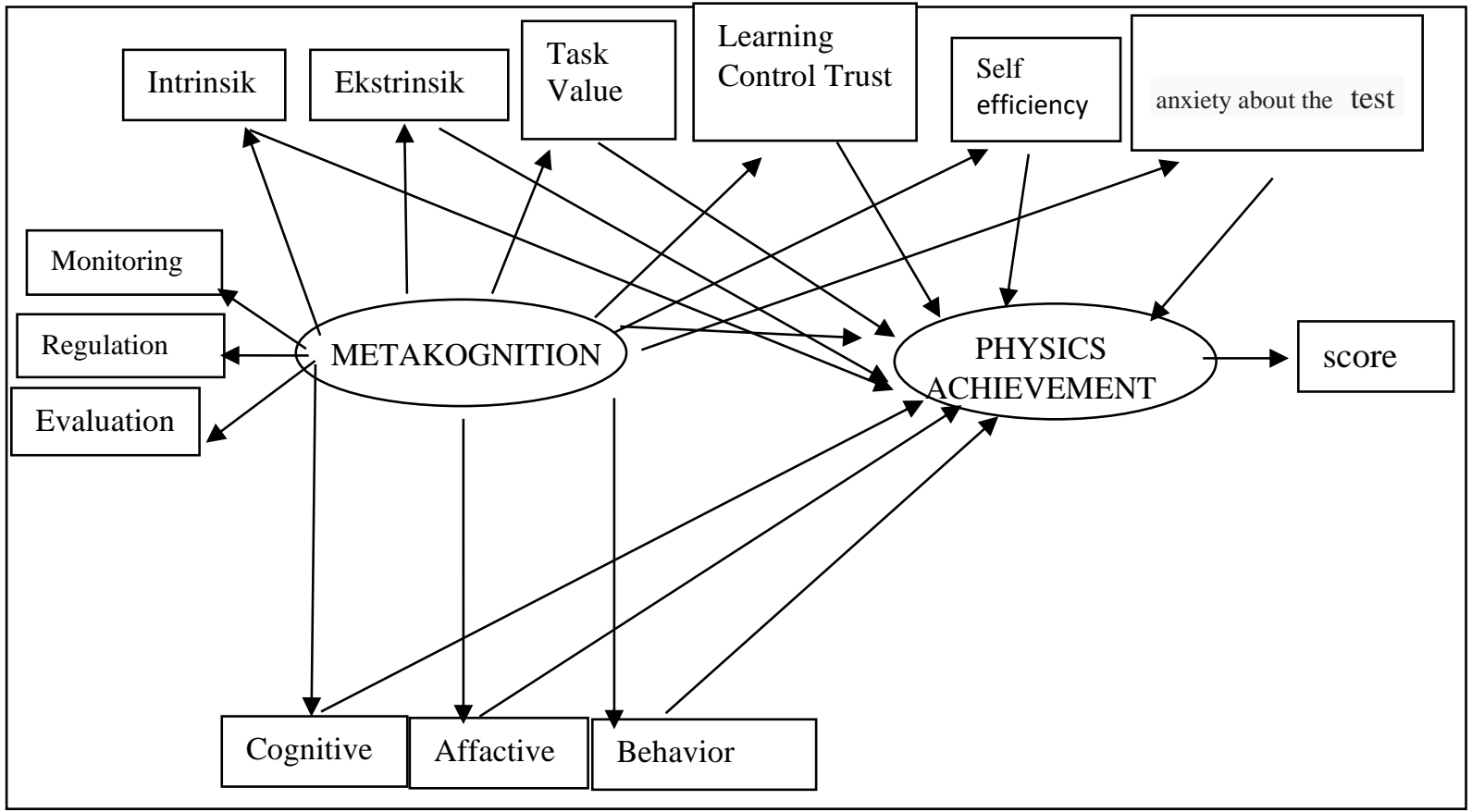

Figure 1: A conceptual model of the interrelationship between Metacognition practice and Dimensions of motivation to learn and the dimensions of commitment to learn with academic achievement.

This study is an exploratory study which is trying to look into the relationship/influence of the practice of Metacognition with dimensions of learning motivation (intrinsic, extrinsic, value of assignments, learning self-control, efficacy and anxiety over tests), dimensions of the commitment of learning (cognitive, affective and behavioural) and achievement of students in Physics. The practice of Metacognition consists of three dimensions, namely monitoring, evaluation and regulation.

Some studies show Metacognition not only controls students' learning to achieve a goal of learning but also improves students ' academic achievement ( Kramarski \& Mevarech, 1997; Tobias \& Everson, 1995; Tasir, Harun \& Zakaria, 2008). Based on the empirical evidence, there are two hypotheses, namely: -

Hypothesis 1: Metacognition has a positive and direct effect on academic achievement.

Meanwhile, Uguroglu (1982) stated that the dimensions of motivation to learn is a variable related to academic achievement and McKay (1984) explained the dimensions of learning motivation consistent factors on academic achievement. Past research found the dimensions of motivation to learn is considered to be positive on the factors of the academic achievements of students 
INTERNATIONAL JOURNAL OF ACADEMIC RESEARCH IN BUSINESS AND SOCIAL SCIENCES Vol. 10, No. 3, March, 2020, E-ISSN: 2222-6990 @ 2020 HRMARS

(Enstwistle, 1980; Schraw et al., 1995). Thus, the hypothesis is a direct link between dimensions of motivation in learning and academic achievement.

Hypothesis 2: The dimensions of learning motivation (intrinsic, extrinsic, value of assignments, learning self-control, efficiency and concern over the test) have a positive and direct effect on academic achievement.

According to Fredricks et al. (2004), commitment to learn also influences academic achievement. The outcome of a review of past research shows that dimensions of commitment to study are considered positive factors effect on students ' academic achievement (Paimin, 2009; Said \& Chandrathevy, 2010; Ogunleye \& Babajide, 2002). The third hypothesis is based on this evidence.

Hypothesis 3: Dimensions of learning commitment (affective, cognitive and behavioral problems) have a positive and direct on academic achievement .

In reviewing the relationship between the dimensions of commitment to learn and academic motivation it is important to determine how these dimensions can be influenced dimension by the practice of Metacognition and how it could affect academic achievement. Therefore the practice of Metacognition is believed to be one of the variables that can affect academic achievement through the dimensions of learning and motivation and commitment to learn. According To Pintrich, Smith, Gracia \& McKeachie (1993), dimensions of learning motivation of efficiency i.e., intrinsic goal orientation, control over the effort and value of assignments are influenced by Metacognition and this finding is also supported by Dawson and Mclnerny (1998); Doljanac (1994); \& Wey (1998), Hammam and Steven (1998) and McKeachie (1993). Ames (1992); Anchor (1994); Anchor and Scevak (1998) and Wey (1998) who found a positive relationship between intrinsic motivation and Metacognition. The value of assignment is also found to have a positive relationship with Metacognition (Hammann \& Steven, 1998).

According to Doljanac (2004) learning control efficacies of belief and self have a positive relationship with the practice of metacognition. However, anxiety over tests is expected to have a negative relationship with Metacognition because individuals with higher learning control will have intensive preparation in the exam. This is supported by VanZile-Tamsen (2001). Therefore, Metacognition will affect dimensions of motivation to learn and thus affect the achievement of students in Physics. In accordance with this, the third and fourth hypotheses are as follows:

Hypothesis 4: There is a positive relationship between Metacognition and direct practice with dimensions of motivation to learn.

Hypothesis 5: There are indirect and positive relationship between the practice of student achievement through Metacognition with dimensions of motivation to learn.

Dimensions of commitment to learn are also expected in connection with the practice of Metacognition because learning is a mental and physical process that brings changes to behavior (Sheal, 1994). To ensure that learning can occur, there should be encouragement for the students to start and continue the learning process. In this aspect, commitment is seen as an effective factor in helping students achieve the desired learning outcomes. Individuals with affective commitment or emotional commitment are able to love the things learned and these things can be done if the students can see potential benefits that they will receive from the help or knowledge learned (Prijosaksono \& Sembel, 2008). Thus they will make metacognition a practice in their learning process. In addition, cognitive commitment also has significant positive influences on the solution of a problem and students tend to work hard and give more of something shown in the involvement of 
behavior and desire to complete a task assigned to them can enhance their metacognition practices Fusco (1995). In addition, behavioural commitment is also expected to influence metacognition practices due to positive practices such as behaviours that represent efforts, diligence, concentration, attention, asking questions, contributing opinions in class discussions, learning, completing homework and taking part in activities involving schools will enhance their metacognition practices as metacognition practices require high internal strength and their commitment to learning. Hence, the sixth and seventh hypotheses are as follows:

Hypothesis 6: The practice of Metacognition has direct and positive relationship on the dimensions of commitment to learn.

Hypothesis 7: The practice of Metacognition has indirect and positive relationship with student achievement through dimensions of commitment to learning.

This hypothesis model is analyzed using Structural Equation Model.

\section{Research Methodology}

This study is a study that uses a quantitative approach that seeks to study the relationship between Metacognition, motivation to learn and commitment with student achievement in Physics among matriculation students who are pursuing their studies in Module 1 and Module 2. This study uses two instruments namely survey method (questionnaire) and a Physics Test (UDF) was constructed to obtain data from respondents who are Matriculation students.

The quantitative approach is a form of study involving data collection and analysis in order to clarify numerical forecast and control the phenomenon under review (Gay, Mills \& Airasian, 2006). Based on this approach, the survey method (survey) is best suited for obtaining data from a sample in the selected study population. The survey method can be used as data collection as this method proves to be more efficient and saves time compared to other methods (Borg \& Gall, 1971; Gay, Mills \&Airasian, 1992).

Information from the sample was obtained using questionnaires for data collection review. Ary and Jacob (1990) argue that using question and answer could involve more respondents with wider coverage and comprehensive while Cates (1990) stated that the main benefit of using questionnaire is that if it is properly constructed and administered, it can produce items that are consistent and reliable.

\section{Sampling Procedure}

The study population was made up of Module 1 and Module 2 students of Penang Matriculation College (KMPP), a college run under the Ministry of Education and located in Pongsu Seribu, Kepala Batas, Pulau Pinang. The students were pursuing a one year programme in the 2011/2012 academic session. The total population comprised about 1318 students consisting of four group lectures for module 1 involving a total of 32 practicums with 25 students in each practicum while module 2 consists of five groups involving 25 practicums with also 25 students in each practicum. From the total, sample studies were selected in accordance with 12 practicums selected for Module 1 and 7 practicums selected for Module 2. A total of 475 students is required as a sample study if the population of 1318 .

A total of 475 questionnaires were distributed to randomly selected students of Module 1 and Module 2 students. However, the total number of questionnaires was 454 as the respondents' total 
INTERNATIONAL JOURNAL OF ACADEMIC RESEARCH IN BUSINESS AND SOCIAL SCIENCES

Vol. 10, No. 3, March, 2020, E-ISSN: 2222-6990 @ 2020 HRMARS

sample rate was 96 per cent of the original samples. This happened because there are practicums which have a small number of students, less than 25 , the number of samples selected to represent each module.

\section{Instrumentation}

In this study, an instrument used in the study to gather information was a questionnaire to measure Metacognition practice, motivation to learn and a commitment to learn and also a Physics Test. The questionnaire was divided into four parts. Part A contains the personal information of students; Part B consists of the items to assess students ' Metacognition in Physics; Section C consists of the items to assess students ' learning motivation in learning Physics and part D contains items to assess the commitment of students towards learning Physics. Each item will be followed by five option answers based on a five point Likert scale with (1) Strongly disagree (STS), (2) Disagree (TS), (3) Agree less (KS), (4) Agree (S) and (5) Strongly Agree (SS). Appendix 9 shows the questionnaire used in this study. Meanwhile, a test was also administered to measure students' achievement in Physics.

\section{Section B: Metacognition Questionnaire}

The Metacognition questionnaire used in this study was constructed and modified from a questionnaire use by O'Niel \& Brown (1997) and Namsoo (1998) to measure the practice of Metacognition and consists of dimension of monitoring, evaluation and regulatory dimension ( Jausovec, 1994); Namsoo, 1998; and Vos, 2001). This questionnaire contains 27 items intended to measure students ' Metacognition practices.

\section{Section C : Learning Motivation questionnaire}

The Learning Motivation questionnaire was adapted from Motivated Strategies for Learning Questionnaire (MSLQ) which was built by Pintrinch et al. (1993b) and used by Anida (2009) in his study of the relationship between the learning environment constructivist and motivation in learning of chemistry subject. The reliability value of the MSLQ questionnaire used by Anida (2009) is 0.75. The MSLQ questionnaire has also been translated into English by Rosna, Fauziah and Sarimah (2001) for their study on the motivation of students in learning courses in Psychology education.

\section{Section D: The questionnaire for students' commitment}

The instrument used to measure the commitment of students to learn Physics in the second semester of the Matriculation programme (SF026) has been translated and adapted from the questionnaire which was constructed by the National Center for School Engagement (NCSE, 2006). The reliability of the original questionnaire conducted in Houston, United States of America is one of 0.80 to 0.90 . The NCSE questionnaire was also used by Spiritual (2009) and the Alpha co-efficient for this scale was 0.87 . Some of the items that are appropriate in the study have been selected and this questionnaire has been translated into English by an English teacher with 19 years' experience. (Spiritual, 2009).

\section{Section E : Physics Diagnostic Test (UPF)}

Part $E$ is a Physics diagnostic test (UPF) which consists of 30 items of multiple choice items. that include a variety of titles contained in the semester 2 (SF 026) Physics syllabus specifically from Chapter Six (Electrostatic) which is "Alternating Current ". The validity of the contents of the items 
INTERNATIONAL JOURNAL OF ACADEMIC RESEARCH IN BUSINESS AND SOCIAL SCIENCES Vol. 10, No. 3, March, 2020, E-ISSN: 2222-6990 @ 2020 HRMARS

in the UPF test paper have been checked by 4 Physics lecturers who have vast experience (up to 14 years) in the field of matriculation physics.

Topics from chapters one to six are specially selected for this study because these topics involve the concept and mathematical application. In addition, these topics involve electrical and electromagnetic concepts which are acknowledged to be difficult topics by students, as many of them involve the concept of conception (Baser, 2006; Cocak, 2007; Twist \& Twist, 2005). Apart from that, the concept covered in the electrical and electromagnetic topics also involve the aspect of the applicability in everyday life as in the technology that is focused on electrical flow where the concept requires an "invisible" picture to feel Its effects in everyday life. As such, we can see that many misconceptions have happened in this topic (Dupin, Jhosua, Demirci \& Cirkinoglu, 2004; Wilantara, 2003).

\section{Research Finding}

The relationship between the practice of Metacognition, Motivation to learn and Commitment to Study Dimension with Physics

This section presents the results of the analysis of Structural Equation Models to test the relationship between the study variables, as shown in Figure 2 . The findings of this analysis are discussed in two stages: (1) Discussions related to measurement model for latent Metacognition variables; and (2) Structural Model linking between latent variables. The results of the structural equation model analysis are shown in Figure 3.

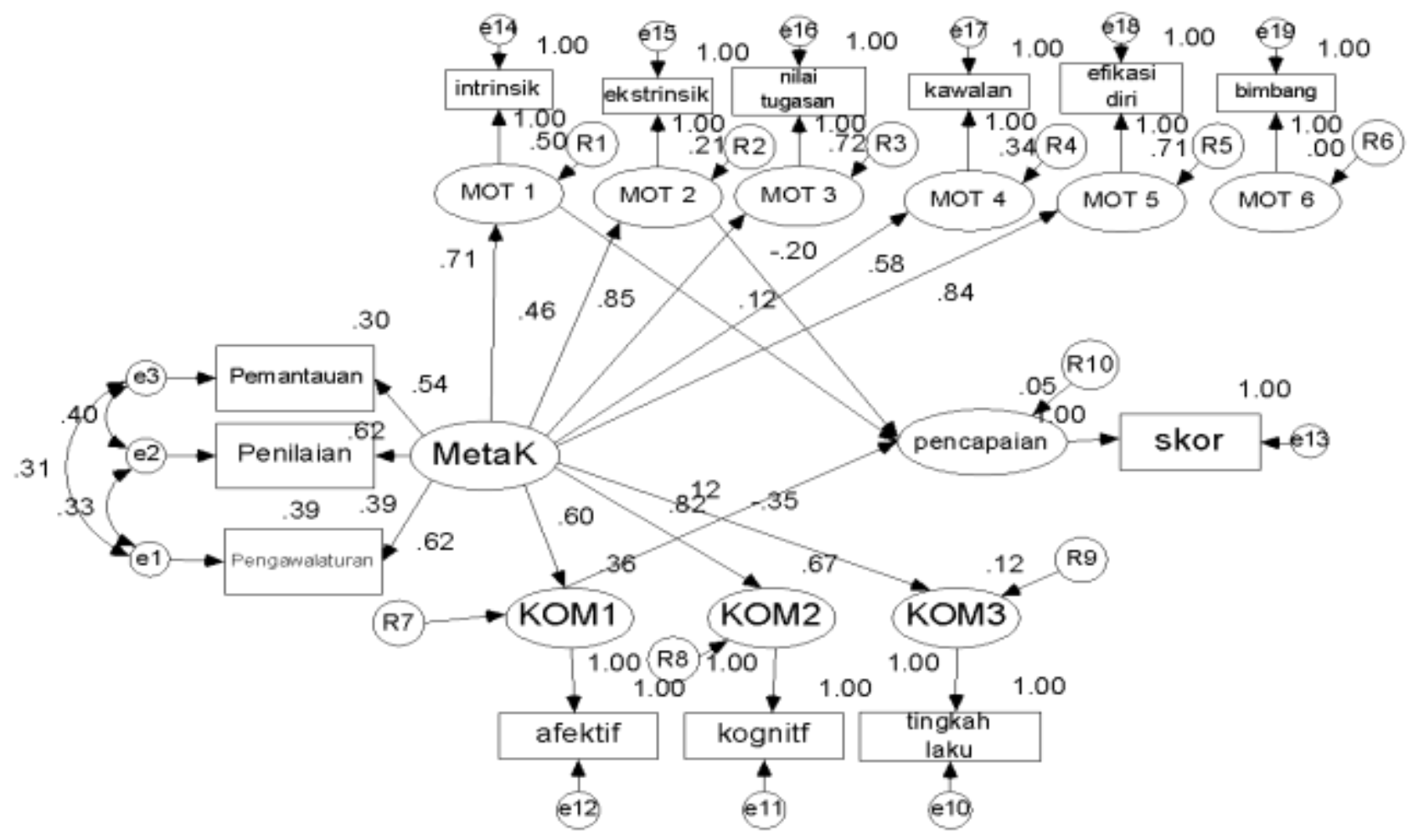

Figure 3: Estimation parameter in the form of standard for Structural Equation Model study Metacognition Measurement Model 
INTERNATIONAL JOURNAL OF ACADEMIC RESEARCH IN BUSINESS AND SOCIAL SCIENCES Vol. 10, No. 3, March, 2020, E-ISSN: 2222-6990 C 2020 HRMARS

The latent Metacognition variable consists of three indicators which are manifest variables namely monitoring, evaluation and regulation. Table 3 and Figure 3 show results of Structural Equation Model analysis for the measurement model.

Table 3: Results of structural equation Model analysis for measurement Model

\begin{tabular}{|c|c|c|c|c|c|}
\hline Correlation & $\begin{array}{l}\text { Non } \\
\text { Standard } \\
\text { Regression } \\
\text { Coefficient }\end{array}$ & SE & $\mathrm{CR}$ & $P$ & $\begin{array}{l}\text { Standard } \\
\text { Regressio } \\
\mathrm{n} \\
\text { Coefficien } \\
\mathrm{t}\end{array}$ \\
\hline $\begin{array}{l}\text { Monitoring } \\
\text { Metacognition }\end{array}$ & 1.00 & 0.001 & 0.001 & 0.001 & 0.62 \\
\hline $\begin{array}{l}\text { Evaluation }<- \\
\text { Metacognition }\end{array}$ & 1.24 & 0.090 & $\begin{array}{l}13.82 \\
9\end{array}$ & 0.001 & 0.62 \\
\hline $\begin{array}{l}\text { Regulation } \\
\text { Metacognition }\end{array}$ & 0.85 & 0.070 & $\begin{array}{l}12.13 \\
9\end{array}$ & 0.001 & 0.54 \\
\hline
\end{tabular}

This finding indicates the load factor of monitoring, evaluation and regularity is in the range of 0.62 and 0.54 . The value of the load factors exceeds the minimum load factor of 0.50 recommended by Hair, Black, Tatham and Anderson (2006). This finding shows the three indicators suitable measuring latent variables of metacognition. Meanwhile, other variables are in the mode of "uniti"

\section{Structural Model}

Figure 3 is a Structural Equations Model showing the relationship between latent variables of the study. Table 4 summarizes the findings of this model. This communication is divided into direct and indirect relationships. 
INTERNATIONAL JOURNAL OF ACADEMIC RESEARCH IN BUSINESS AND SOCIAL SCIENCES

Vol. 10, No. 3, March, 2020, E-ISSN: 2222-6990 C 2020 HRMARS

Table 4 Summary of Relationship Model findings

\begin{tabular}{|c|c|c|c|c|c|}
\hline Equation/ Correlation & $\begin{array}{l}\text { Non } \\
\text { standard } \\
\text { Regressio } \\
n \\
\text { Coefficien } \\
t\end{array}$ & SE & $\mathrm{CR}$ & $P$ & $\begin{array}{l}\text { Non } \\
\text { Standard } \\
\text { Regression } \\
\text { Coefficient }\end{array}$ \\
\hline $\begin{array}{l}\text { Intrinsic Motivation } \leftarrow \\
\text { Metacognition }\end{array}$ & 0.49 & 0.039 & 12.52 & $\begin{array}{l}0.00 \\
1 \\
\end{array}$ & 0.71 \\
\hline $\begin{array}{l}\text { Extrinsic Motivation } \leftarrow- \\
\text { Metacognition }\end{array}$ & 0.62 & 0.071 & 8.732 & $\begin{array}{l}0.00 \\
1 \\
\end{array}$ & 0.46 \\
\hline $\begin{array}{l}\text { Value of task motivation } \leftarrow \\
\text { Metacognition }\end{array}$ & 0.91 & 0.064 & 14.299 & $\begin{array}{l}0.00 \\
1\end{array}$ & 0.85 \\
\hline $\begin{array}{l}\text { Trust motivation } \leftarrow \text { Control } \\
\text { Metacognition }\end{array}$ & 0.43 & 0.040 & 10.760 & $\begin{array}{l}0.00 \\
1 \\
\end{array}$ & 0.59 \\
\hline $\begin{array}{l}\text { Self-efficacy motivation } \leftarrow \\
\text { Metacognition }\end{array}$ & 1. 45 & 0.102 & 14.178 & $\begin{array}{l}0.00 \\
1 \\
\end{array}$ & 0.84 \\
\hline $\begin{array}{l}\text { Achievement } ₫ \text { Affective } \\
\text { Commitment }\end{array}$ & 0.693 & 0.294 & 2.355 & $\begin{array}{l}0.01 \\
9\end{array}$ & 0.12 \\
\hline $\begin{array}{l}\text { Achievement } \longleftarrow \text { Intrinsic } \\
\text { motivation }\end{array}$ & 0.984 & 0.413 & 2.295 & $\begin{array}{l}0.02 \\
2 \\
\end{array}$ & 0.12 \\
\hline $\begin{array}{l}\text { Achievement } \longleftarrow \text { Extrinsic } \\
\text { Motivation }\end{array}$ & -0.822 & 0.198 & -4.146 & $\begin{array}{l}0.00 \\
1\end{array}$ & -0.20 \\
\hline $\begin{array}{l}\text { Affective Commitment } \leftarrow \\
\text { Metacognition }\end{array}$ & 0.58 & 0.052 & 11.027 & $\begin{array}{l}0.00 \\
1 \\
\end{array}$ & 0.60 \\
\hline $\begin{array}{l}\text { Cognitive Commitment } \leftarrow \\
\text { Metacognition }\end{array}$ & 1.398 & 0.100 & 13.947 & $\begin{array}{l}0.00 \\
1 \\
\end{array}$ & 0.82 \\
\hline $\begin{array}{l}\text { Behavioral Commitment } \leftarrow \\
\text { Metacognition }\end{array}$ & -0.387 & 0.056 & -6.891 & $\begin{array}{l}0.00 \\
1 \\
\end{array}$ & -0.352 \\
\hline
\end{tabular}

\section{Direct Relationship}

Table 4 and Figure 3 show that there is no direct relationship between Metacognition and performance. Meanwhile the dimensions of motivation like value of assignment motivation, learning control and its efficiency is also found to be not having a direct relationship with the exception of the dimension of intrinsic motivation $[\beta=0.12 ; p=0.022]$ and dimension of extrinsic motivation $[\beta=-$ $0.20 ; p=0.001]$. For the commitment to learn dimensions, only the affective commitment showed a positive and significant relationship with achievement [ $\beta=0.12 ; p=0.019]$. Metacognition is found to show a direct positive link and significant with Intrinsic motivation $[\beta=0.71 ; p=0.001]$, extrinsic motivation $[\beta=0.46, p=0.001]$, value of assignment motivation $[\beta=0.85 ; p=0.001]$, learning selfcontrol $[\beta=0.59 ; p=0.001]$ and self-efficacy $[\beta=0.84 ; p=0.001]$. All dimensions of learning commitment are also found to be positively and significantly influenced by metacognition [affective 
INTERNATIONAL JOURNAL OF ACADEMIC RESEARCH IN BUSINESS AND SOCIAL SCIENCES Vol. 10, No. 3, March, 2020, E-ISSN: 2222-6990 @ 2020 HRMARS

commitment: $\beta=0.60 ; p=0.001$; Cognitive commitment: $\beta=0.82 ; p=0.001$ ] except for behavioral commitment: $\beta=-0.35 ; p=0.001$ ] which has a negative relationship.

\section{Indirect Relationship}

Based on Figure 3, there is indirect relationship between Metacognition and performance through the dimensions of motivation to learn and study commitments. The results of the analysis show Metacognition has indirect relationship with achievement through intrinsic and extrinsic motivation and through affective commitment.

Table 5 shows the effects between variables in this study.

\begin{tabular}{llcl}
\hline Relationship & & & Effect of influence \\
\hline Metacognition $\longrightarrow$ & Intrinsic Motivation $\longrightarrow$ & Achievement & $0.71 \times 0.12=0.085$ \\
\hline Metacognition $\longrightarrow$ & Extrinsic Motivation & Achievement & $0.46 \times 0.20=0.092$ \\
\hline Metacognition $\longrightarrow$ & Affective Commitment & Achievement & $0.60 \times 0.12=0.072$ \\
\hline
\end{tabular}

Overall, this model is found to be compatible with the data of the study based on the value of the index of compatibility (goodness-of-fit-indices). Value of khi $(\chi 2)$ is $[\chi(61)=232.20, p \leq .05]$ is significant but value $(\chi 2) / d f$ is 3.9 and less than 5 . Kline (1998) suggests that the ratio ( $\chi 2) / d f$ is 3 or less is a good indicator for compatibility with the data model. There is also a view that value $(\chi 2) / d f$ less than 5 is an indication of compatibility with the data model (Ferdinand, 2002; Hair, 1998; Saemah \& Phillips, 2006). Meanwhile, the value of TLI (Tucker-Lewis Fix Index) and CFI (Comparative Fix Index) is more than $0.90(\mathrm{TLI}=0.906, \mathrm{CFI}=0.927)$. RMSEA values. 079 which is less than the value of the model RMSEA (Root Mean Square Error of Approximation) is 0.08 adopted in this study. This compatibility index shows a model compatible with the data.

\section{Discussion of Findings and Summary \\ Relationship Between Dimensions of Metacognitive Practice, Motivation to Learn and Commitment to Learn with Achievement in Physics.}

Analysis of the hypothesized model shows that there is no direct relationship between Metacognition and achievement but there exists indirect relationship through the dimensions of motivation to learn, which is intrinsic motivation, extrinsic motivation, value of assignment, learning control, efficacies of belief, and self-commitment dimension, namely affective learning, cognitive learning and behavioral learning. This finding refutes with the theories of Metacognition that discuss the relationship with the student learning process. Among them are Flavell (1979) who sums up that Metacognition plays an important role in the learning process. Similarly, Brown (1987) States that active learning that regulates and improves students' actions will improve their learning outcomes. The finding also denies the findings of several previous studies such as the findings of the Darabie Study (2000) and the findings of experimental-shaped studies by Kincannon, Gleber and Kim (1999) who reported a positive relationship between metacognition and achievements. However, the findings of this study were in line with the study of Piatt (1991) and Allon, Gutkin \& Feruning (1994), which showed that there is no direct relationship between metacognition and performance. Although there is no significant relationship between metacognition and Physics, this does not mean students do not 
INTERNATIONAL JOURNAL OF ACADEMIC RESEARCH IN BUSINESS AND SOCIAL SCIENCES Vol. 10, No. 3, March, 2020, E-ISSN: 2222-6990 ¿ 2020 HRMARS

practice metacognition in their learning. Metacognition processes indeed exist during the students' classroom interaction. (Goos, 1995).

The results from Structural model confirmed that the practice of Metacognition influences value of assignment self-efficacies, extrinsic motivation, intrinsic motivation and learning control. The results of the study also indicate that only the intrinsic motivation and extrinsic only became a significant mediator to Metacognition in practice affect achievement.

The influence of practice of Metacognition and the dimensions of motivation it is recommended by some researchers. Kluwe (1982) connects Metacognition with self-efficacies. The efficacies of self can affect how students approached and involved themselves in learning tasks (Hammann \& Steven, 1998). Borkowski, Carr, Pressley and Relinger (1990) also associate Metacognition with some dimensions of motivation. Their positive correlation hypothesized reduction practices among Metacognition affective aspects where students produce expectations about Metacognition acting self-efficacies that will motivate the individuals face the task learning difficulty.

Theory of Achievement Goal Orientation on the other hand suggested that the relationship between the intrinsic motivation with the behavior of a person's learning process where students oriented intrinsic associated with the desire to understand a topic with deep and report on the use of learning strategies more effective. Ames and Archer (1998), stating the student oriented extrinsic associated with use of the surface in learning strategy and does not help improve learning in the long run (Archer \& Scevak, 1998).

Review of past research also shows the value of assignment and learning to link learning orientation. The value of assignment refers to the knowledge whether the content of the subject is interesting, useful and important to students. The findings of this study also showed a significant positive relationship with the value of task (Pintrich, Smith, \& McKeachie Garcia, 1993) and belief in learning control (Hammann \& Steven, 1998; Wey, 1998) with metacognition. However, the dimensions of anxiety over tests available did not show a significant relationship with Metacognition and this is consistent with findings by VanZile-Tamsen (2001). But test anxiety has a significant relationship with Metacognition and performance (Lynch, 2006)

According to Skinner and Belmort (1993), students who have high commitment show continuous involvement in learning activities and followed by positive emotions. Students will focus efforts and commitment and display positive emotions including passion, optimism, curiosity and interest. The findings of this study show a direct relationship between the affective commitment with achievement. However, the study found that there was no relationship between the dimensions of commitment to learn which are cognitive and affective commitment with students ' academic achievement contrary to findings by Bloom (1982) indicating the availability of a direct relationship between the dimensions of affective commitment and cognitive commitment, with academic achievement. 
INTERNATIONAL JOURNAL OF ACADEMIC RESEARCH IN BUSINESS AND SOCIAL SCIENCES Vol. 10, No. 3, March, 2020, E-ISSN: 2222-6990 @ 2020 HRMARS

The results of the structural model found that there is no direct relationship between the significant achievements but Metacognition practices have an indirect relationship with achievement through intrinsic and extrinsic dimension motivation and affective commitment. This decision explains the relationship between Metacognition with the dimension of motivation and learning dimension of commitment in contributing to the student learning process. Indirect relationship between the practice of Metacognition with achievement through learning motivation and learning commitment is in line with past research the rest about the relationship between these variables. Among them were studies by Ladine and Stewart (1998), Hammann and Steven (1998) which reported a direct relationship between metacognition motivation, Fusco (1995) explained direct relationship between the dimension of commitment and metacognition and research by Ladine (1994), Darabie (2000), Romainville (1994) and Swanson (1990) reported an indirect relationship between metacognition and performance through another variable.

It is concluded that metacognition variable is an important contributor to the variation in academic achievement through motivational learning and learning commitment.

\section{References}

Yahaya, A., Ramli, J., \& Boon, Y. (2010). Sumbangan Sikap Tehadap Pencapaian Pelajar Dalam Mata Pelajaran Matematik: Sejauhmanakah Hubungan ini Relevan? Fakulti Pendidikan Universiti Teknologi Malaysia. Retrived From http://eprints.utm.my/id/eprint/2355/.

Prijosaksono, A., \& Sembel, R.(2008). Belajar Sukses. Retrieved From http://www.sinarharapan.co.id/ekonomi/mandiri/2004/0406/man01.html.

Matrikulasi, B. (2010). Huraian Sukatan Pelajaran Fizik. Putrajaya: Bahagian Matrikulasi Kementerian Pelajaran Malaysia

Broussard, S. C., \& Garrisson, M. E. (2004). The Relationship between classroom motivation and Academic achievement in elementary School-aged children. Family Consumer Science Research Journal, 33(2), 106-120.

Brown, M. B. (2009). Academic Motivation: Strategies for Students. National Association of school Phychologists, September 2009, Vol 38, pp.1.

Eccles, J., Midgley, C. (1989). Stage/enviriment fit: Developmentally appropriate classrooms for adolescents. In R. ames \& C. Ames (Eds)., Research on motivation in education, (3), pp. 139-181. New York: Academic Press.

Fredricks, J.A., Blumenfeld, P.C., \& Paris. A.H. (2004). School Engagement Potential of the Concept, State of Evidance. Review of Educational Research, 74, 1, 59-109. http://www.adi.org/journal/resources/SCJSpringSummer2009.pdf

Gay, L. R., Mills, G. E., \& Airasian, P. (2006). Education Research : Competencies for Analysi and Application( 8th Edition). New Jersey: Prentice Hall Inc.

Hattie, J. (2003). Teacher Professional Development: Its not an event, it's a process. Retrieved from www.cord.org/uploasfiles/Harwellpapaer.pdf

Haliday, D., Resnick, R., \& Walker, J.(2001). Fundamentals of Physics (6th ed). United State :Wiley

Hair, J. E., Aderson, R. E., Tatham, R. L., \& Black, W. C. (1998). Multivariate Data Analysis. Edisi ke - 5. Upper Saddle River: Prentice Hall. 
INTERNATIONAL JOURNAL OF ACADEMIC RESEARCH IN BUSINESS AND SOCIAL SCIENCES

Vol. 10, No. 3, March, 2020, E-ISSN: 2222-6990 @ 2020 HRMARS

Haller, F. P., Chil, D. A., \& Walberg, H. J. (1998). Can Comprehension be taught? A quantitative synthesis of metacognitive studies. Educational Researcher, 17(9), 5-8.

Hammann, L. A., \& Stevens, R. J. (1998). Metacognitive awareness assessment in self-relugulated learning and performance measures in an Introductory Educational Psychology course. Educational Resources Information Center. Retrieved from https://files.eric.ed.gov/fulltext/ED424249.pdf

Jausovec, N. (1994). Flexible Thinking: An Explanation for Individual differences in ability. New Jersy: Hampton.

Mastor, K. A., Hamzah, M. F., Mustapha, R., Yacob, N. R., \& Jaafar, K. (2006). Kajian Perbandingan Tahap Kesesuaian, Komitmen, Gaya pembelajarandan prestasi akademik pelajar - pelajar kejuruteraan kurikulum bukan OBE dan OBE. Fakulti Kejuruteraan.Universiti Kebangsaan Malaysia. Retrived from http://www.ukm.my/p3k/images/sppb06/1.pdf

Kucukozer \& Kocakulah. (2007). Secondary School Students' Misconceptions about simple electric circuit. Journal of Turkish Science Education 4(1). January 2007. http://www.tused.org/internet/tused/archive/V4/i1/text/tusedv4i1s8.pdf

Krejcie, R. V., \& Morgan, D. W. (1970). Determining sample size for research activities. Educational and Psychological Measurement, 30(3), 607-610.

Lay, A. N. (2007). Persepsi Pelajar Pelbagai Gaya Pembelajaran Terhadap Penerapan Strategi Metakognitif Guru. Universiti Teknologi Malaysia. Retrieved from http://eprints.utm.my/6553/1/layahnammp052035d07ttt.pdf

Lee, N. H., Chang, A. S. C., \& Lee, P. (2001). The Role of Metacognition in the Learning of Mathematics Among Low - achieving Students'. Teaching And Learning. National Institute of Education. Nanyang Technological University. 2(2). Pp.18-29.

Larkin, J. H., McDermott, J., Somin, D. P., \& Simon, H. A.,(1980). Model of competence in solving physics problems. cognitive science $4(1), 317-345$.

Ibrahim, M. A., \& Buang, H. (2010). Hubungan Penguasaan Konsep Fizik dengan Minat Dan Kemahiran Belajar Dalam Kalangan Pelajar Fizik Di Universiti Teknologi, Fakulti pendidikan, UTM. Retrieved from http://eprints.utm.my/11313/1/Hubungan_Penguasaan_Konsep_Fizik_Dengan_Minat_Dan Kemahiran_Belajar_Dalam_Kalangan_Pelajar_Fizik_Di_Universiti_Teknologi_ Malaysia.pdf

Adnan, M. A., \& Yusoff, M. A. (2010). Motivasi Pembelajaran pengaturan kendiri dan prestasi akademik: Satu kajian di kalangan pelajar asasi pengajian Islam Universiti Malaya, Nilam Puri. Journal of Al-Tamaddun 4(1). Retrieved from http:// grad.yiu.ac.th/main/images/journal/.../57-71.pdf [12/1/2012]

Ministry of Education Malaysia. (2006). Pelan Induk Pembangunan Pendidikan 2006-2010. Kuala Lumpur: Ministry of Education.

Darabie, M. (2000). The relationship between college-level Jordanian students' metacognitive awareness strategies and their reading comprehension achievement in English as a foreign language. Dissertation Abstracts International 61 (07A):2646.

Idris, N. (2010).Penyelidikan Dalam Pendidikan. Malaysia: Mc Graw Hill Education Sdn Bhd. 
INTERNATIONAL JOURNAL OF ACADEMIC RESEARCH IN BUSINESS AND SOCIAL SCIENCES

Vol. 10, No. 3, March, 2020, E-ISSN: 2222-6990 C 2020 HRMARS

Said, N. H. M., \& Kuppusamy, C. (2010). Hubungan Sikap (Komitmen, Emosi, Berwawasan) dengan pencapaian akademik pelajar PKPG (SPT, SPN,SPH) tahun akhir di fakulti pendidikan, UTM Skudai. Retrieve from http://eprints.utm.my/11186/1/Hubungan_Sikap.pdf

Ogunleye, B. O., \& Babajide, V. F. T. (2011). Commitment to science abnd gender as determination of student Achievement and practical skills in Physics. Ireland International Conference on Education 2016, Ireland. Retrived from http://www.cented.org.ar/noticias/2016_10_24_Dublin/IICE-2016-Proceedings.pdf

Pusat Perkembangan Kurikulum. (2001). Pembelajaran Secara Konstruktivisme. Kuala Lumpur: Dewan Bahasa Dan Pustaka.

Pintrich, P. R., Smith, D. A. F., Gracia, T., \& McKeachie, W. J. (1991). A manual for the use of the learning motivated strategies for learning questionnaire (MSLQ) National Center for Research to improve post secondary teaching and learning.

Paulsen, M. B., \& Gentry, J. A. (1995). Motivational Learning strategies and academic performance: A study of the college finace classroom: Financial practice \& education 5 (1), 78-89.

Pintrich, P. R., \& DeGroot, E. V. (1990). Motivational and self regu layed learning component of classroom Academic performance. Journal of education psychology 82 (1) p 33-40.

Poh, L. Y. (2011). Physics for Matriculation semester 2. Third Edition. Oxford Fajar. Selangor.

Ahmad, K. R. (2005). Mengukur keberkesanan Sekolah: Satu perspektif daripada kerangka konsep “ the balanced scored".

http://iab.academia.edu/RusminiKuAhmad/Papers/524763/Kerangka_Komprehensif_ Untuk_Penambahbaikan_Sekolah_Berkesan._Satu_Kajian_Eksploratori

Arbaar, R. (2009). Guru Berkualiti dan hubungannya dengan komitmen belajar pelajar. Jurnal Pendidikan Malaysia 35(2)(2010): 61-69.

Hashim, R. A., Rahman, F. A., Abdullah, S. S. (2001). Comfirmatory Factor Analysis of the Bahasa Malaysia Version of the Motivated Strategies for Learning Questionnaire (MSLQ). International Conference on Measurement and Evaluation in Education 2001, Penang .

Atan, R. M. (2007). Hubungan Antara Sikap Dengan Pencapaian PelajarTingkatan 4 dalam Tajuk Daya. Jurnal Pendidikan Universiti Teknologi Malaysia. Jilid 12 Oktober 2007, Hal: 50-60. http://eprints.utm.my/10418/1/RohanaMohdAtan2007_Hubungan AntaraSikapDenganPencapaian.pdf

Redish, E. F., Scherr, R. E., \& Tuminaro, J. (2006). Reverse-Engineering the solution of a simple physics problem: why Learning physics is harder than it looks. The Physics Teacher 44 (5), 293300, 2006.

Riley, A. H. J. (1997). Student Achivement and attitude in Mathematics. An evaluation of the Twenty First Century Mathematics Center for urban schools.

Rutter, K. L., Smith, B. P., \& Hall, H. C. (2005). The Effect of gender and grade level on the motivational needs of family and consumer science students. Journal of Family and consumer science education, 23(2), 2006.

Rahman, S., \& Phillps, J. A. (2006). Hubungan antara kesedaran Metakognisi, Motivasi dan Pencapaian Akademik Pelajar Universiti. Jurnal Pendidikan 31, 2007, hal:21-39. http://www.ukm.my/penerbit/jurnal_pdf/jpend31_02.pdf 
INTERNATIONAL JOURNAL OF ACADEMIC RESEARCH IN BUSINESS AND SOCIAL SCIENCES

Vol. 10, No. 3, March, 2020, E-ISSN: 2222-6990 @ 2020 HRMARS

Sulaiman, S., Abdullah, F.A.P., \& Ali, M. (2007).Kemahiran metakognitif dalam kalangan pelajar sekolah Menengah di negeri Johor dalam menyelesaikan masalah Fizik. Universiti Teknologi Malaysia. Retrived from http://eprints.utm.my/4566/1/75161.pdf

Tasir, Z., Harun, J., \& Zakaria, N. W. (2008). Tahap Kemahiran Metakognitif Dalam menyelesaikan masalah matematik. Fakulti Pendidikan, Universiti Teknologi Malaysia. Retrived From http://eprints.utm.my/7783/1/P37-Zaidatun.pdf

Zan, R. (2000). A Metacognition Interaction In mathematics At University Level. International Journal of Mathematical Education in Science and Technology. 37(1).

Sulaiman, Z. (1995). Pengurusan Pencapaian Akademik Pelajar Sekolah Menengah di Luarbandar: Kes empat buah sekolah di negeri Kedah Darul Aman. Retrieved from http://etd.uum.edu.my/772/1/ZALEHA_BT._SULAIMAN.pdf

Ismail, Z., Samsudin, M. A., \& Zain, A. N. M. (2005). Kesan pengajaran kontekstual ke atas pencapaian pelajar dalam Fizik. Universiti Sains Malaysia. Retrieved from http://eprints.usm.my/10527/1/Kesan_Pengajaran_Kontekstual_Terhadap_Motivasi_Dan_P encapaian_Pelajar_Sekolah_Dalam_Fizik.pdf

Zakaria, Z. B. M. ( 2007). Hubungan Gaya pembelajaran dengan pencapaian akademik. Retrieved from http://eprints.utm.my/6470/1/ZubaidahBegamMFP.pdf

Zimmerman, B. J. (1990). Self Regulated learning and academic achievement: an overview. Educational Psychologist 25(1) , 3-17.

Zimmerman, B. J., \& Risemberg, R. (1997). Becoming a self-regulated writer: A social cognitive perspective. Contemporary Educational Psychology 22(2), 73-122.

Tobias, S. (1985). Test Anxiety Interference Defective skill and cognitive capacity. Educational psychologist 20(6), $135-142$.

Vallerand, R. J., Pelletier, L. G., Blais, M. R., Briere, N. M., Senecal, C., Vallieres, E. F. (1992). The academic motivation scale: A measure of intrinsic, extrinsic and amotivation in education. Educational and Psychological measurement, 52(4). Retrieved from

http://epm.sagepub.com/content/52/4/1003.abstract

Schunk, D. H. (1991). Self-efficacy and academic motivation. Educational Psychologist, 26(3-4), 207231. Retrieved From http://www.tandf.co.uk/journals/

Tahir, Y., \& Boon, Y. (2011). Tahap Kecerdasan Emosi Dan Hubungannya Dengan Komitmen Guru Dalam Bekerja Dalam Kalangan Guru Mata Pelajaran Teras Tahun Enam. Fakulti Pendidikan, Universiti Teknologi Malaysia 81310 Johor, Malaysia. Journal of Edupress, Volume 1 September 2011, 187- 196 . Retrieved from http://eprints.utm.my/17063/1/JOE-1-2011024.pdf.

Paimin, M. R. (2009). Hubungan sikap dengan pencapaian dalam mata pelajaran Matematik tingkatan 2 di dua buah sekolah di kawasan Skudai, Johor. Retrieved from www.fp.utm.my/.../MOHDROSMADIBP060042D

Schraw, G. \& Dennison, R.S. (1994). Assessing metacognitive awareness. Contemporary Educational Psychology 19(4),460-475.

Schraw, G., Horn, C, Thorndike-Christ, T \& Bruning, R. (1995). Academic goal orientation and student achievement. Contemporary Educational Psychology 20(3),359-368.

Entwisle, D., Alexander, K., Cadigan, D., \& Pallas, A. (1986). The schooling process in first grade: Two sample a decade apart. American Educational Research Journal, 23(4), 587-613. 
INTERNATIONAL JOURNAL OF ACADEMIC RESEARCH IN BUSINESS AND SOCIAL SCIENCES

Vol. 10, No. 3, March, 2020, E-ISSN: 2222-6990 @ 2020 HRMARS

Kramarski, B., \& Mevarech, Z. R. (2003). Enhancing Mathematical reasoning in the classroom. The effects of cooperative leraning and metacognitive training. American Educational Research Journal, 40(10), 281-310.

Hataway, R., Loesch, E., Sharp, S., \& Davis, A. S. (2003). Factors influencing first year undergraduate science and engineering academic confidence. Women in engineering Proactive network Conference 2003, Chicago, Illinois.

Lee, K. H. (2008).Kajian Terhadap Faktor- Faktor yang mempengaruhi pencapaian pelajar 4SPP dan 4SPF Dalam Subjek Fizik . Universiti Teknologi Malaysia. Retrieved from http://eprints.utm.my/id/eprint/11382/ 